\title{
Acyclic Ribooxacarbenium Ion Mimics as Transition State Analogues of Human and Malarial Purine Nucleoside Phosphorylases
}

\author{
Erika A. Taylor ${ }^{\S}$, Keith Clinch ${ }^{\ddagger}$, Peter M. Kelly, ${ }^{\ddagger}$, Lei Li ${ }^{\S}$, Gary B. Evans ${ }^{\ddagger}$, \\ Peter C. Tyler ${ }^{\star}$ and Vern L. Schramm ${ }^{\S *}$.
}

\begin{abstract}
${ }^{\S}$ Department of Biochemistry, Albert Einstein College of Medicine at Yeshiva University, 1300 Morris Park Avenue, Bronx, New York, 10461, USA. ${ }^{\ddagger}$ Carbohydrate Chemistry Team, Industrial Research Ltd., Lower Hutt, New Zealand,
\end{abstract}

General Synthetic Approach. All chemicals were analytical grade or the highest quality commercially available. The synthetic approaches to the compounds listed in the Table (see below) are based on procedures published earlier. ${ }^{1-6}$ Detailed methods for previously unreported compounds will be reported elsewhere.

Enzymes and Inhibitors. HsPNP and PfPNP were prepared as a $\mathrm{His}_{6}$-N-terminal fusion proteins as previously published. ${ }^{7,8}$ Protein concentrations were determined by UV absorbance using the extinction coefficients of $28830 \mathrm{M}^{-1} \mathrm{~cm}^{-1}$ and $17930 \mathrm{M}^{-1} \mathrm{~cm}^{-1}$ at $280 \mathrm{~nm}$ for HsPNP and PfPNP, respectively. ${ }^{9}$ Inhibitor concentrations were also determined by UV absorbance using the published extinction coefficient of $9540 \mathrm{M}^{-1} \mathrm{~cm}^{-}$ ${ }^{1}$ at $261 \mathrm{~nm} .{ }^{10}$ Kinetic parameters used in the determination of inhibition constants were 
determined independently to be $K_{\mathrm{M}}=5 \mu \mathrm{M}$ for PfPNP and $K_{\mathrm{M}}=40 \mu \mathrm{M}$ for HsPNP for inosine, which are consistent with published values. ${ }^{7,10,11}$

Enzyme inhibition assay. Purine nucleoside phosphorylase activity was determined by monitoring the conversion of inosine to uric acid via the change in absorbance at $293 \mathrm{~nm}$ in assay mixtures containing $50 \mathrm{mM}$ potassium phosphate, $\mathrm{pH} 7.4$, with xanthine oxidase, (60 milliunits) at $37^{\circ} \mathrm{C}$ (extinction coefficient for uric acid is $\varepsilon_{293}$ $\left.=12.9 \mathrm{mM}^{-1} \mathrm{~cm}^{-1}\right)$. The kinetics for slow-onset inhibition and $K_{\mathrm{i}}$ measurement were performed using inhibitor concentrations ranging from $10 \mu \mathrm{M}$ to $2 \mathrm{nM}$ and an enzyme concentration of $1 \mathrm{nM}$. The $\mathrm{Ki}$ values were determined by fitting the initial rate and inhibitor concentrations to the following expression of competitive inhibition:

$$
\left(V_{\mathrm{o}}^{\prime} / V_{\mathrm{o}}\right)=\left(K_{\mathrm{M}}+[\mathrm{S}]\right) /\left(K_{\mathrm{M}}+[\mathrm{S}]+\left(K_{\mathrm{M}}[\mathrm{I}] / K_{\mathrm{i}}\right)\right)
$$

where $V^{\prime}{ }_{\mathrm{o}}$ is the initial rate in the presence of inhibitor, and $V_{\mathrm{o}}$ is the initial rate in the absence of inhibitor, [I] is the inhibitor concentration, and [S] is the substrate concentration. $^{12,13}$ This expression is valid only under the condition where the inhibitor concentration is 10 times greater than the enzyme concentration. In conditions where inhibitor concentration does not exceed ten times the enzyme concentration the effective inhibitor concentration was obtained by the expression:

$$
I^{\prime}=I-\left(1-V_{\mathrm{o}}^{\prime} / V_{\mathrm{o}}\right) E_{\mathrm{t}}
$$

where $I^{\prime}$ is the effective inhibitor concentration, $V^{\prime}{ }_{\mathrm{o}}$ and $V_{\mathrm{o}}$ are the initial rate in the presence and absence of inhibitor, and $E_{\mathrm{t}}$ is the total enzyme concentration.

In cases where slow onset inhibition was observed, where the inhibitor reached a tighter binding thermodynamic equilibrium with the enzyme, the equilibrium dissociation constant $\left(K_{\mathrm{i}}^{*}\right)$ was obtained by fitting the rates to the following equation for competitive inhibition

$$
\left(V^{\prime}{ }_{\mathrm{o}} / V_{\mathrm{o}}\right)=\left(K_{\mathrm{M}}+[\mathrm{S}]\right) /\left(K_{\mathrm{M}}+[\mathrm{S}]+\left(K_{\mathrm{M}}[\mathrm{I}] / K_{\mathrm{i}} *\right)\right)
$$


with $[\mathrm{I}]$ concentrations being corrected as above. ${ }^{14}$

In the Table shown below, an entry of N/A in the $K_{\mathrm{i}}^{*}$ column indicates that no slow-onset inhibition was observed. An entry in the $K_{\mathrm{i}}^{*}$ column indicates the presence of a slow-onset phase of inhibition with the constant being determined as competitive inhibition after the second steady-state is achieved. 


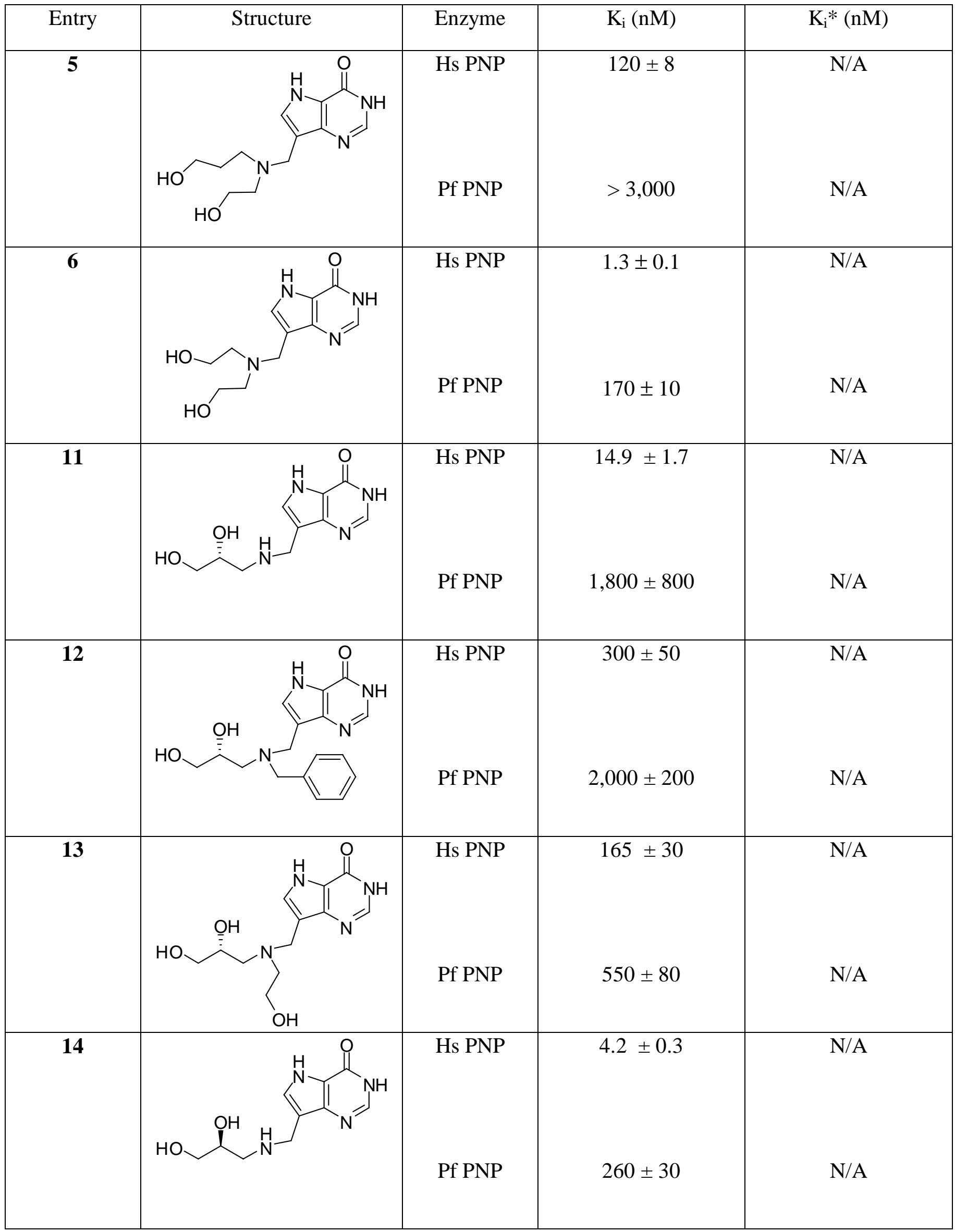




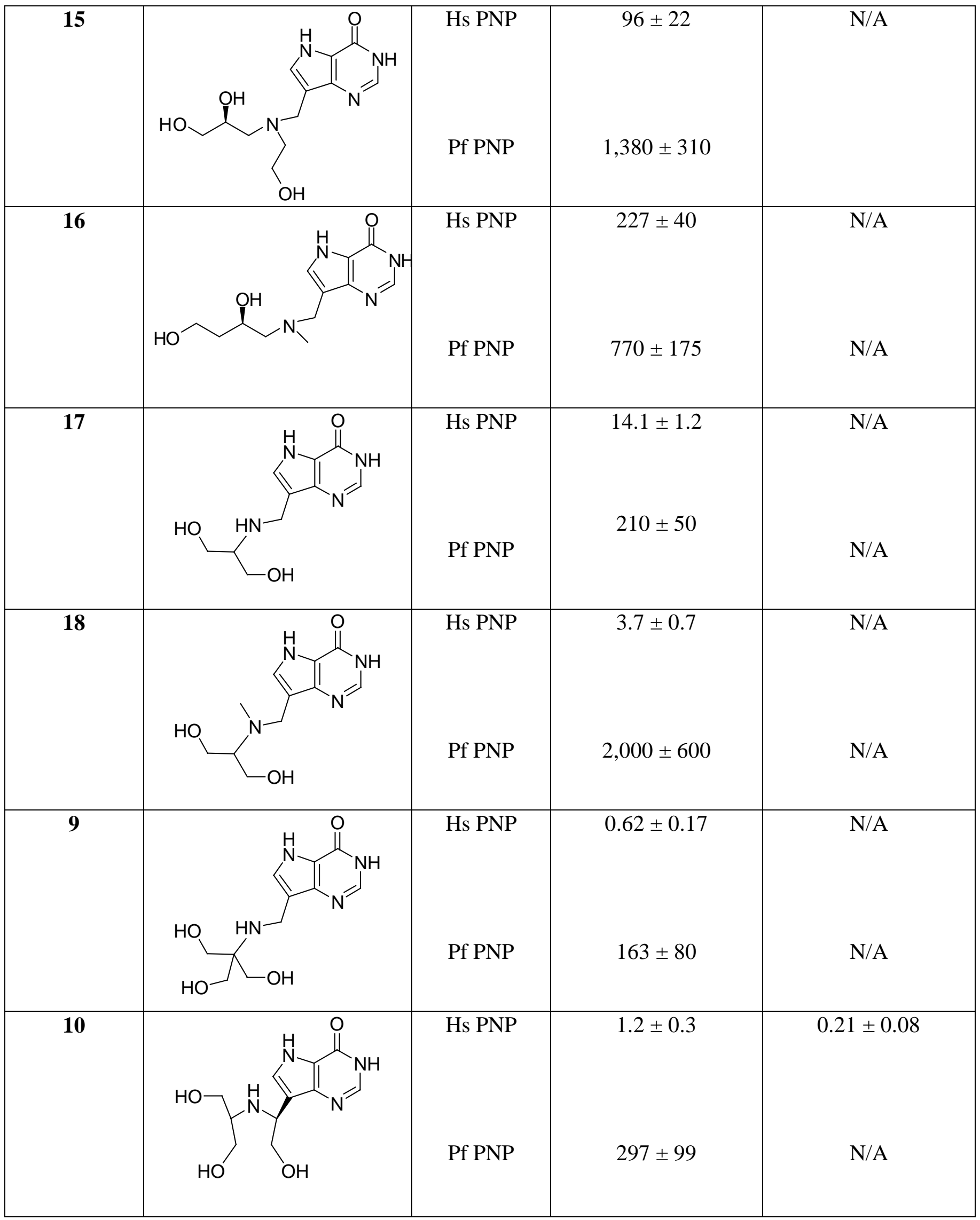




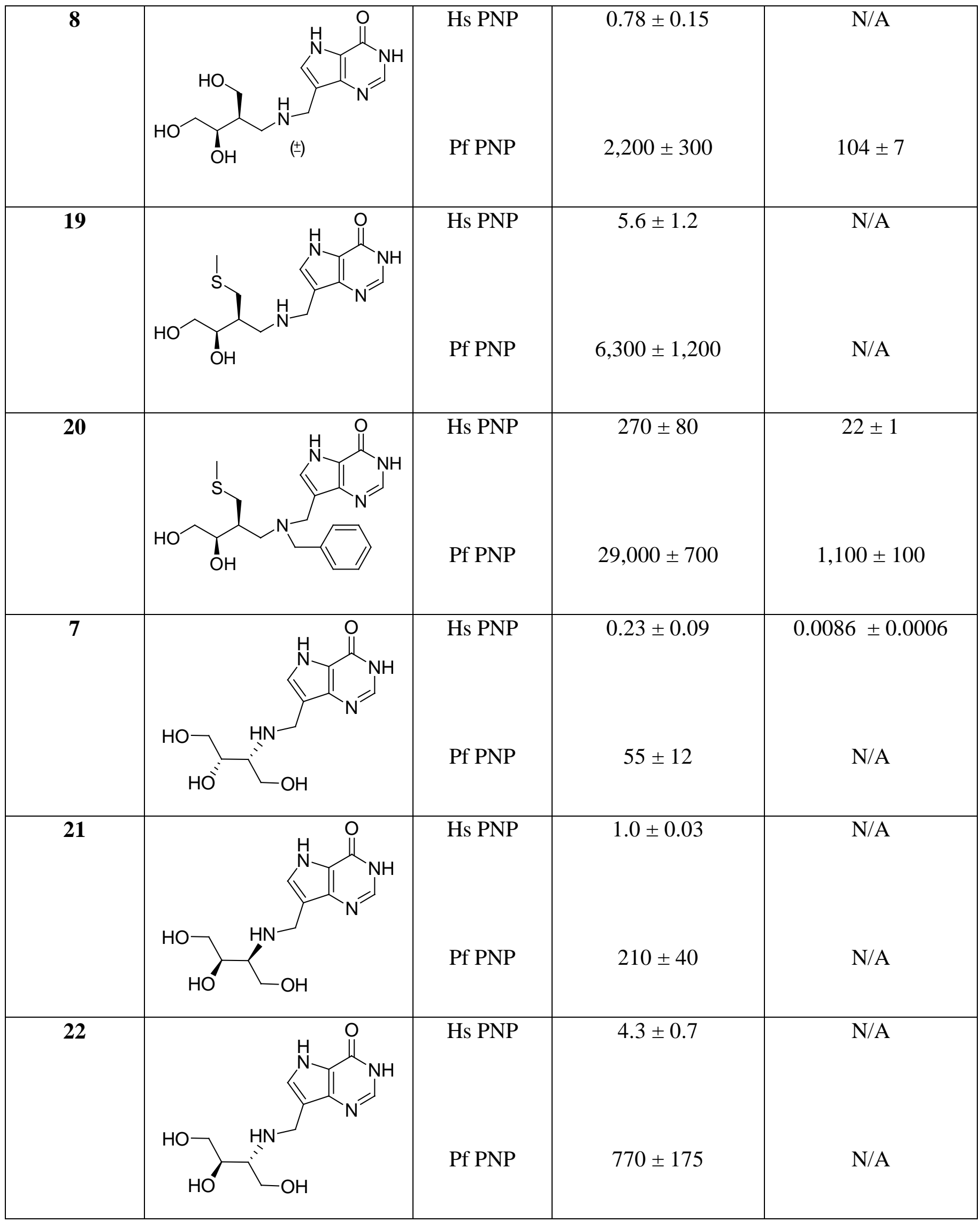




\begin{tabular}{|l|l|l|l|l|}
\hline 23 & Ns PNP & $5.2 \pm 0.7$ & N/A \\
\hline
\end{tabular}




\section{References}

1. Evans, G. B. Aust. J. Chem. 2004, 57, 837-854.

2. Evans, G. B.; Furneaux, R. H.; Hausler, H.; Larsen, J.S.; Tyler, P. C. J. Org. Chem. 2004, 69, 2217-2220.

3. Evans, G. B.; Furneaux, R. H.; Lewandowicz, A.; Schramm, V. L.; Tyler, P. C. J. Med. Chem. 2003, 46, 3412-3423.

4. Evans, G. B.; Furneaux, R. H.; Lewandowicz, A.; Schramm, V. L.; Tyler, P. C. J. Med. Chem. 2003, 46, 5271-5276.

5. Schramm, V. L.; Tyler, P,C. Curr. Top. Med.. Chem.. 2003, 3, 525-540.

6. Clinch, K.; Evans, G.B.; Fleet, G.W.; Furneaux, R.H.; Johnson, S.W.; Lenz, D.H.; Mee, S.P.; Rands, P.R.; Schramm, V.L.; Taylor Ringia, E.A.; Tyler, P.C. Org. Biomol. Chem. 2006, 4, 1131-1139.

7. Lewandowicz, A.; Schramm, V. L. Biochemistry, 2004, 43, 1458-1468.

8. Shi, W.; Ting, L. M.; Lewandowicz, A.; Tyler, P. C.; Evans, G. B.; Furneaux, R. H.; Kim, K.; Almo, S. C.; Schramm, V. L. J. Biol. Chem. 2004, 279, 18103-18106.

9. Extinction coefficients were determined using the Protparam tool (www.expasy.org/tools/protparam/html).

10. Miles, R. W.; Tyler, P.C.; Furneaux, R. H.; Bagdassarian, C. K.; Schramm, V. L. Biochemistry, 1998, 37, 8615-8621.

11. Erion, M. D.; Takabayashi, K.; Smith, H. B.; Kessi, J.; Wagner, S.; Honger, S.; Shames, S. L.; Ealick, S. E. Biochemistry, 1997, 36, 11725-11734.

12. Merkler, D. J.; Brenowitz, M.; Schramm, V. L. Biochemistry 1990, 29, 8358-8364.

13. Singh, V.; Shi, W.; Evans, G. B.; Tyler, P. C.; Furneaux, R. H.; Almo, S. C.; Schramm, V. L. Biochemistry 2004, 43, 9-18. 
14. Singh, V.; Evans, G. B.; Lenz, D. H.; Mason, J. M.; Clinch, K.; Mee, S.; Painter, G.

F.; Tyler, P. C.; Furneaux, R. H.; Lee, J. E.; Howell, P. L.; Schramm, V. L. J. Biol. Chem. 2005, 280, 18265-18273. 